\title{
Treatment of periodontal disease with guided tissue regeneration technique using a hydroxyapatite and polycaprolactone membrane
}

\author{
[Tratamento da doença periodontal pela técnica da regeneração tecidual guiada utilizando uma \\ membrana de hidroxiapatita e policaprolactona] \\ L.M.A. Martins, F.L. Valente, E.C.C. Reis, R.V. Sepúlveda, A.P.L. Perdigão, A.P.B. Borges* \\ Universidade Federal de Viçosa - Viçosa, MG
}

\begin{abstract}
The aim of this study was to evaluate the use of a malleable membrane composed of hydroxyapatite $(60 \%)$ and polycaprolactone $(40 \%)$ as treatment of periodontal disease experimentally induced in dogs. A bone defect of standardized dimensions was created between the roots of the third and fourth premolar of 12 dogs for periodontal disease induction. Six dogs had the defect covered by the membrane and six dogs received only standard treatment for periodontal disease, also applied to dogs in the treated group. The animals were clinically monitored during the experiment. Radiographs were taken after surgery and at 60 days after treatment initiation. Clinical attachment level was also assessed in those moments. On the 60th day, dental sample of all animals, containing tooth, defect and periodontal tissues, were harvested, fixed in formalin and analyzed by microtomography and histology. During the experimental period, the animals showed no pain and purulent discharge, however, there was dehiscence in $50 \%$ of animals and membrane exposure in five out of six animals in the treated group. Clinical attachment level showed no difference between groups. Radiographs showed radiopacity equal to the alveolar bone in both groups. The microtomography revealed that the control group had higher bone volume in the defect compared to the treated group; however, the furcation was not filled by new alveolar bone in any animal. Histological analysis revealed that junctional epithelium invasion was lighter in the control group. New bone was only observed in the apical edge of the defect in both groups. Although the composite is biocompatible and able to keep the space of the defect, it did not promote periodontal tissue regeneration within 60 days of observation.
\end{abstract}

Keywords: biomaterial, animal model, dentistry

\section{RESUMO}

O objetivo do presente trabalho foi avaliar a utilização de membrana moldável constituída por hidroxiapatita (60\%) e policaprolactona (40\%) como tratamento da doença periodontal, induzida experimentalmente em cães. Um defeito ósseo de dimensões padronizadas foi realizado entre as raízes do terceiro e do quarto pré-molares de 12 cães para indução da doença periodontal. Todos os cães receberam tratamento padrão para doença periodontal, e seis desses animais foram tratados também com a aplicação da membrana sobre o defeito. Os animais foram acompanhados clinicamente durante o experimento. Radiografias foram realizadas no pós-operatório e aos 60 dias após o início do tratamento. O nível clínico de inserção também foi avaliado nesses momentos. Aos 60 dias, a amostra dental de todos os animais contendo o dente, o defeito e os tecidos periodontais foi coletada, fixada em formol $e$ analisada por microtomografia e histologia. Durante o período experimental, os animais não apresentaram dor e secreção purulenta, entretanto houve deiscência em $50 \%$ dos animais e exposição de membrana em cinco dos seis animais do grupo tratado. Nível clínico de inserção não apresentou diferença entre os grupos. As imagens radiográficas mostraram radiopacidade igual ao osso alveolar em ambos os grupos. A microtomografia revelou que o grupo controle apresentou maior volume ósseo no

Recebido em 29 de março de 2015

Aceito em 7 de abril de 2016

*Autor para correspondência (corresponding author)

E-mail: andrea@ufv.br 
defeito em relação ao grupo tratado, no entanto, em todos os animais, a região de furca não foi preenchida por novo osso alveolar. A análise histológica revelou que a invasão por epitélio juncional foi mais discreta no grupo controle. Osso novo foi apenas observado na borda apical do defeito em ambos os grupos. Embora o compósito seja biocompatível e tenha sido capaz de manter o espaço do defeito, ele não promoveu a regeneração dos tecidos periodontais no período de 60 dias de observação.

Palavras-chave: biomaterial, modelo animal, odontologia

\section{INTRODUCTION}

Periodontal disease is a disease resulting in the destruction of tissue supporting the teeth by the inflammatory response to pathogenic microflora that forms on them (Pihlstrom et al., 2005). In addition to the loss of teeth, other more serious diseases may be associated with this disorder, as local conditions such as greater predisposition to pathological fractures of jaw (Legendre, 2003), and systemic, since periodontal disease acts as an aggravating factor for cardiovascular disease, diabetes, pneumonia and glomerulonephritis (Pihlstrom et al., 2005). Conventional treatment includes surgical access to the periodontal defect through retail muco-gingival, plaque, and calculus scraping, and repositioning the flap; however, this treatment allows the defect invasion by junctional epithelium and connective tissue, thus preventing repair of alveolar bone and periodontal ligament (Macedo et al., 2006). The use of composites of hydroxyapatite (HA) associated with polycaprolactone (PCL) as a biomaterial is desirable due to its chemical and morphological characteristics. The synthetic HA is a biocompatible material, bioactive and osteoconductive (Borges et al., 2000). The PCL is a biocompatible and bioabsorbable polyester, both being desired characteristics in search of a biomaterial (Elzein, 2004) and, when associated with HA, allow to obtain a porous and malleable membrane (Rezwan et al., 2006), able to maintain the space of the defect, allowing for better and greater migration of osteoinductive components (Fujihara et al., 2004).

The need for new and more affordable materials and new techniques for use in medicine and dentistry, both in human and in veterinary, is evident. $\mathrm{We}$ intend to evaluate the biocompatibility, osteoconductive and new bone formation with the use of a lower cost product, using only Brazilian technology.

\section{MATERIAL AND METHODS}

The methodology used in this work was prepared in accordance with current legislation and approved by the Ethics Committee of the institution in Animal Use (protocol 014/2012).

For this study, 12 healthy, female, adult dogs, weighing between 10 and $15 \mathrm{~kg}$, housed in individual pens, were used. During the experiment, they received a commercial feed and water ad libitum with an adjustment period of 30 days. The induction of the periodontal disease model followed was as described by Sepúlveda et al. (2014). The animals were sedated (acepromazine $0.1 \mathrm{mg} / \mathrm{kg}$, intramuscular) and general anesthesia was induced with propofol $(6 \mathrm{mg} / \mathrm{kg}$, intravenous) and maintained with isoflurane and oxygen mixture. For a better intraoperative analgesia, the inferior alveolar nerve was blocked with $0.5 \%$ ropivacaine $(1.0 \mathrm{mg} / \mathrm{kg})$.

The animals were then subjected to a first surgical procedure for producing the periodontal defect. A mucoperiosteal flap in the region of the third and fourth premolars of the mandible was incised and moved apically, exposing the alveolar bone. In the alveolar bone of each of these teeth class II furcation defects were performed, with the aid of a conical FG drill coupled to a high-revving engine, in the following dimensions: $6 \mathrm{~mm}$ in the corono-apical direction from the cementoenamel junction until the more apical edge of the defect; $7 \mathrm{~mm}$ in the mesial-distal direction; and $3 \mathrm{~mm}$ in depth from the facial surface from the root to the most lingual surface of the bone defect, between the two roots. The exposed roots received curettage to remove Sharpey fibers and cement. Then, the periodontal defect was filled with molding polyester to prevent regeneration and promote its chronicity. The flap was repositioned and sutured in simple interrupted pattern with polyglactin 910. At this time, radiographs were taken of the operated regions. 
Postoperatively, analgesia was performed with tramadol $(6 \mathrm{mg} / \mathrm{kg}$, subcutaneous, every 8 hours for 3 days). Daily, the animals had surgical wounds cleaned with $0.12 \%$ chlorhexidine solution and the surgical wound was examined for three weeks, evaluating bleeding, pus, and dehiscence.

After 21 days of induction of periodontal disease, a second surgical procedure was performed for removal of the molding polyester and conducting prophylaxis of periodontal disease with scaling and polishing. A plaque control program was instituted, with daily brushing and application of $0.12 \%$ chlorhexidine, twice daily, for two weeks.

Two weeks after the above procedure, the application of the membrane from the treated group of animals was performed. The defects were exposed and curettage was done for granulation tissue removal. Before being applied, the membrane was heated at $100^{\circ} \mathrm{C}$ to become malleable, facilitate their handling and adjustment in the defect. After cooling, the membrane was positioned, covering the defect, so that its edge exceeded at least $2 \mathrm{~mm}$ in the mesial, distal and apical direction beyond the defect. A titanium screw was used to secure the membrane to the alveolar bone (Fig. 1). Then, the gingiva was placed over the membrane and sutured to the adjacent gingiva. New radiographs were taken. The animals were given analgesics (tramadol, $6 \mathrm{mg} / \mathrm{kg}$ subcutaneously every 8 hours for 3 days) and antibiotics (doxycycline, $10 \mathrm{mg} / \mathrm{kg}$, orally, for 10 days) after surgery and were given a daily oral cavity clean with $0.12 \%$ chlorhexidine solution until complete healing of the surgical wound. Additionally, for the control of dental plaque, the animal's teeth were brushed every 48 hours until the end of the study and application of chlorhexidine $0.12 \%$ in the implantation sites of the membranes. In addition, the animals were fed with pasty diet.

Local clinical examination consisted of daily observation of the surgical wound for two weeks and 60 days after surgery, evaluating bleeding, purulent discharge, dehiscence and membrane exposure. Pain sensitivity was assessed by the animal's reaction to touching the wound, assigning scores: 0 - when the animal allowed the touch and did not show reaction; 1 - when the animal allowed the touch, but expressed pain reaction; 2 - when the animal did not allow the touch.

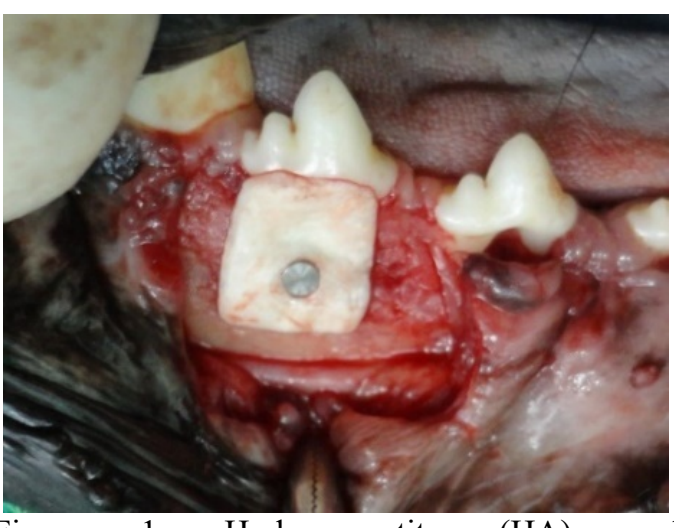

Figure 1. Hydroxyapatite (HA) and polycaprolactone (PCL) membrane attached by a screw on the experimentally induced bone defects in the third premolar root of a dog before repositioning the gingival flap and suturing for assessing periodontal regeneration.

The clinical attachment level (CAL) was measured from the cementoenamel junction to the place of adhesion of the junctional epithelium, i.e., the bottom of the periodontal sulcus before treatment and 60 days after surgery. The proportion of the regression of the disease was obtained by dividing the second value obtained by the former.

At 60 days after the start of treatment, new radiographs were taken, which were analyzed in the presence or absence of the lamina dura, the space of periodontal ligament, and comparing the radiopacity between the defect areas with the alveolar bone. The regularity of edges was also evaluated.

The mandibule fragments containing defects, teeth associated with them and the gingiva of the buccal region were collected. The fragments were fixed in formalin and sent for microtomography analysis (MicroCT40, Scanco, Switzerland) which provided the percentage of defective bone volume to total volume of the defect (BV/TV); the trabecular thickness (Tb.Th.); distance between trabeculae (Tb.Sp.), and trabeculae number (Tb.N.). A sample of an intact third premolar of an animal not carrying periodontal disease who had died by natural causes in the veterinary hospital of the institution 
was collected and analyzed by reference. For this analysis, the region of interest was defined by the following dimensions: (1) $0.4 \mathrm{~mm}$ below the cementoenamel line to the upper limit; (2) $1 \mathrm{~mm}$ above the height of the defect originally designed for the lower limit, in order to ensure that the bone included in the region of interest correspond to newly formed bone; (3) the root canals for lingual limits; (4) buccal edge of the root to vestibular limits.

After tomographic analysis, the samples were decalcified in formic acid and sodium citrate solutions, and submitted for routine histological processing being dehydrated in increasing alcohol solutions, diaphanized in xylene and embedded in paraffin. Three non-sequential longitudinal sections, $5 \mathrm{~mm}$ thick, at least 50 microns away from each other were obtained from each sample and stained with hematoxylin and eosin. The material was analyzed qualitatively; tissues and cells present were characterized, as well as inflammatory infiltrate, bone formation, cementum and periodontal ligament.

The clinical attachment levels, in millimeters, were evaluated by paired $t$ test. The relative proportions were compared among groups by the Kruskal-Wallis test. The variables from the tomographic analysis (BV/TV, Tb.N, Tb.Th, and $\mathrm{Tb} . \mathrm{Sp}$ ) were submitted to the Student t test to compare means. All statistical tests were performed in SigmaPlot 11.0 software at 5\% significance level.

\section{RESULTS AND DISCUSSION}

Postoperatively, after the placement of the membrane, five animals in the control group had mild bleeding for two days. Despite the great vascularity of the alveolar bone, which is also related to its great regenerative capacity (Fígun and Garino, 1994), the presence of small hemorrhage in animals can be explained by the correct juxtaposition of gingival flap in the control group. The presence of the membrane in the treated group may have favored the clot retention. In the control group, only two animals showed dehiscence of points, both on the sixth day after surgery. The healing of the gingival flap in animals occurred between 7 and 10 days after surgery. Thus, the observed dehiscence did not lead to changes in the outcome of the experiment. In the treated group, three animals showed dehiscence in the immediate postoperative period, and consequently membrane exposure. In both groups, the score for pain sensitivity was 1 in the first two days and 0 thereafter. This observation indicates the proper use of pain medication for animals. Three animals lost their membranes on 22,35 , and 40 days after surgery.

At the end of the two weeks of clinical analysis, all six animals had mild gingival recession and exposure of the membrane (Fig. 2). In a similar study, Reis et al. (2011), using membranes composed of PLGA/calcium phosphate, exposure of the membrane were observed in only one animal and gingival recession was resolved after a few days. The membrane used in this experiment is less flexible than the biomaterial used by these authors, which may partly explain the difference observed. No animal showed purulent discharge over the 60 days.

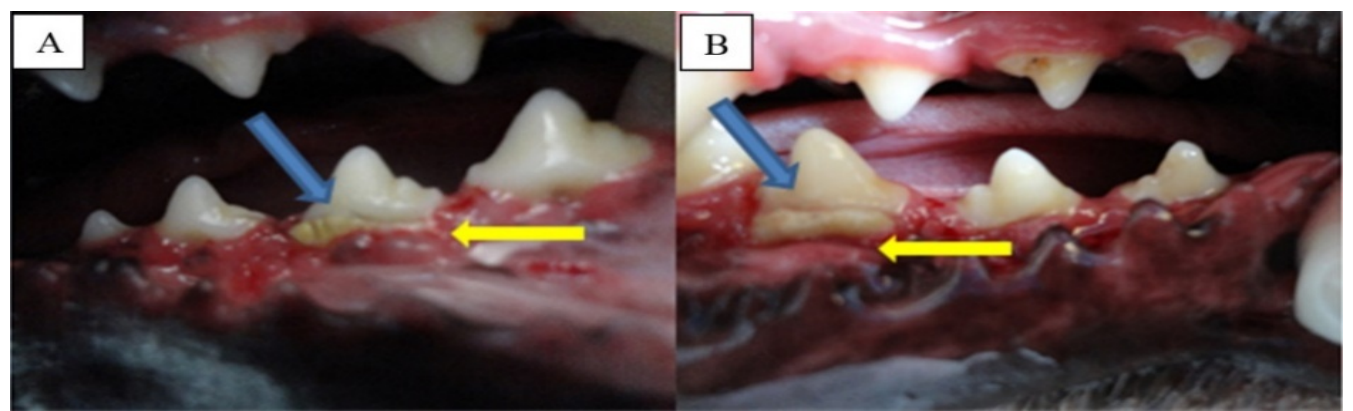

Figure 2. Membrane exposure (blue arrows) in the group treated with gingival recession (yellow arrows) at 60 days after placing the membrane on the third (A) and fourth premolar (B) of a dog in the treatment of experimentally induced periodontal disease. 
The clinical attachment level measured immediately before application of the membrane and before removal of samples (60 days after the application of the membrane) showed significant regression in both groups, $\mathrm{P}<0.001$ for the control group and $\mathrm{P}=0.002$ for treated (Fig. 3). However, the proportion of regression of clinical attachment level to 60 days, given by the ratio between the two measures, was not different between groups or analyzed teeth $(\mathrm{P}=0.430)$ (Tab. 1), indicating that the membrane can act similarly to the alveolar bone as a support for gingival adhesion.

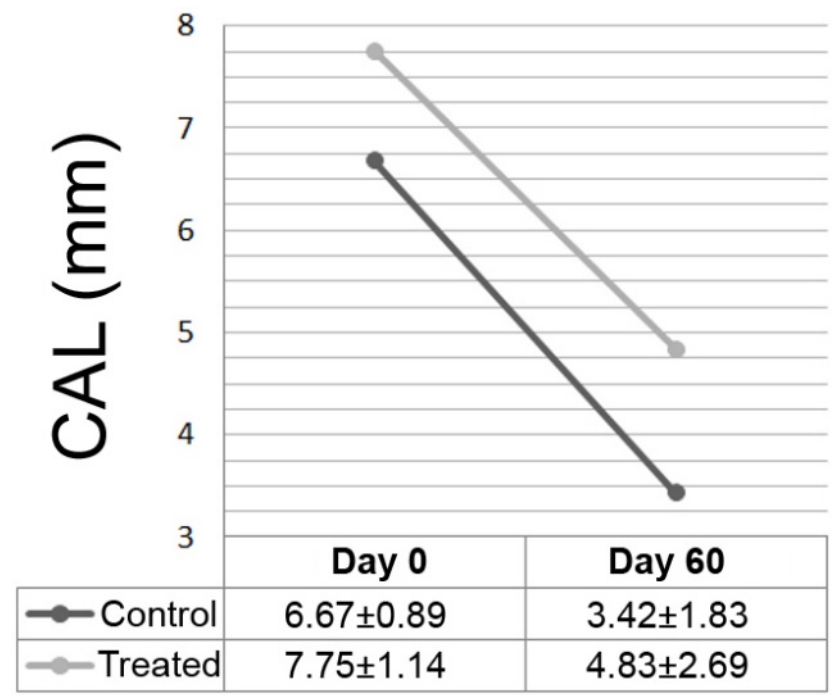

Figure 3. Mean and standard deviation of clinical attachment level (CAL in $\mathrm{mm}$ ) of dogs that received hydroxyapatite and polycaprolactone membrane for the treatment of experimentally induced periodontal defects. Day 0 is the time of application of the membrane. Day 60 corresponds to the 60 th day after the implantation of the membrane. Paired t test $\alpha=0.05$; control: $\mathrm{P}<0.001$; treated: $\mathrm{P}=0.002$.

Table 1. Average ratio of the regression of clinical attachment level according to the treatment and analyzed tooth in dogs for evaluation of periodontal regeneration using a hydroxyapatite and polycaprolactone membrane

\begin{tabular}{lll} 
Group & $3^{\circ} \mathrm{PM}$ & $4^{\circ} \mathrm{PM}$ \\
\hline Control & $0.417 \mathrm{Aa}$ & $0.607 \mathrm{Aa}$ \\
Treatment & $0.670 \mathrm{Aa}$ & $0.534 \mathrm{Aa}$ \\
\hline
\end{tabular}

PM: Premolar. Same uppercase letters within a column and same lowercase letters within a line do not differ. Kruskal-Wallis $\alpha=0.05 ; \mathrm{P}=0.430$.

Radiographic analysis performed immediately after the third surgical procedure revealed, in both groups, lower radiopacity of the defect area compared with the surrounding bone (Fig. 4A and B). Also, in both groups, it was not possible to observe the presence of periodontal ligament or the lamina dura. As for radiopacity, we observed that both the control group and the treated group at 60 days showed radiopacity in the defect area equal to that of the adjacent alveolar bone (Fig. 4C and D). All images evaluated demonstrated a defect fill, with exposed furcation, without the presence of edges. 


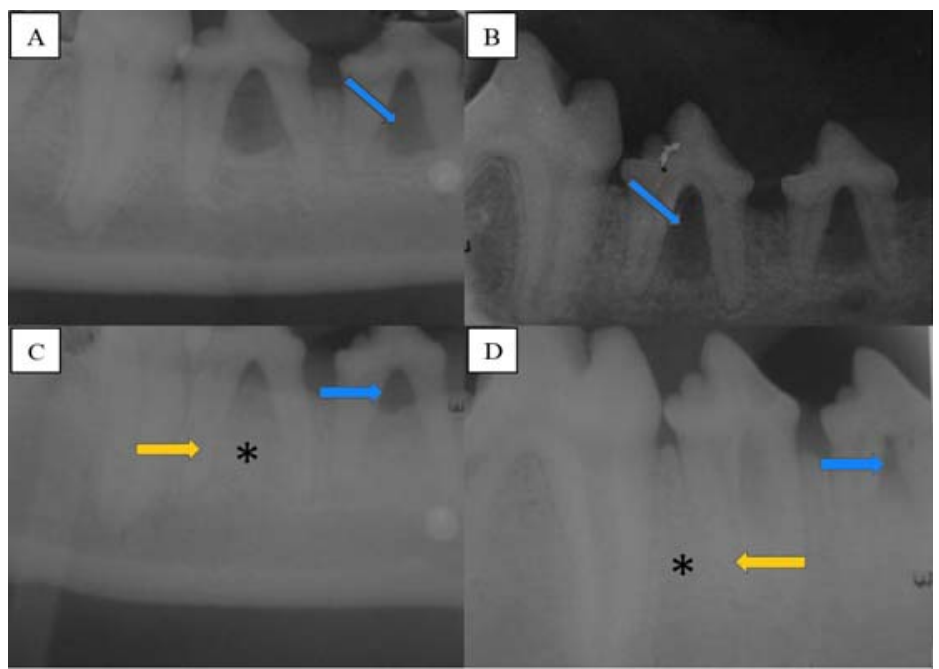

Figure 4. Radiographs obtained immediately after application of the membrane (A: treated; B: control) and 60 days after application of the treatment (C: treated; D: control) using hydroxyapatite and polycaprolactone membrane for regeneration of periodontal defects experimentally induced in dogs.

The values obtained in micro tomography indicate a lower bone growth in the treated group. However, only $\mathrm{BV} / \mathrm{TV}$ showed a statistically significant difference, $\mathrm{P}=0.042$ (Tab. 2). These results demonstrate that the membrane was not able to promote bone regeneration more efficiently than the control group after 60 days and, in addition, the treatment can be adversely affected by the regeneration, as also observed by Reis et al., (2013) with polyhydroxybutyrate and hydroxyapatite membrane. These effects may be due to the presentation of the membrane used, as Reis et al. (2011), with a complex topography membrane were able to demonstrate, by micro tomography, bone regeneration in similar defects. Other membranes have also demonstrated a positive effect (Kinoshita et al., 2008; Iwata et al., 2009). Still analyzing the values for BV/TV (Tab. 2), it can be inferred that the coefficient of variation, given by the ratio between the standard deviation and the mean in the treated group is 3.5 times higher than in the control group (respectively, 0.748 and 0.213 ), which may be a result of the influence of individual factors, either in response to treatment of the animal or variations related to the technical approach of the implant, as well as the loss of the membrane during the treatment period. Deliberador et al. (2006) also observed experimental variations consistent with a response of biological variation among animals, which can be behavioral, genetic, biochemical, or physiological (Selvig, 1994). Furthermore, the values for BV/TV presented by both groups were well below the intact sample. This observation is because, in this sample, the entire defect area was filled by alveolar bone while in both studied groups, the majority of the area of interest included in the calculation of this variable was not occupied by tissue with density compatible with bone (Fig. 5).

Table 2. Means, standard deviations and $\mathrm{P}$ values for morphometric data obtained by computed microtomography in dogs for evaluation of periodontal regeneration using a hydroxyapatite and polycaprolactone membrane

\begin{tabular}{lllll} 
Parameters & Intact & Control & Treated & $\mathrm{P}^{*}$ \\
\hline BV/TV & 0.83 & $0.36 \pm 0.08$ & $0.20 \pm 0.15$ & 0.042 \\
Tb.N & 3.82 & $1.63 \pm 0.91$ & $1.00 \pm 0.75$ & 0.215 \\
Tb.Th & 0.47 & $0.26 \pm 0.07$ & $0.18 \pm 0.07$ & 0.087 \\
Tb.Sp & 0.15 & $1.24 \pm 0.72$ & $1.82 \pm 0.76$ & 0.207 \\
\hline
\end{tabular}

BV / TV: trabecular bone volume fraction; Tb.N: number of trabeculae; Tb.Th: thickness of the trabeculae; and Tb.Sp: distance between the trabeculae. * $\mathrm{P}$ values for comparison between control and treated groups, Student's $\mathrm{t}$ test. 


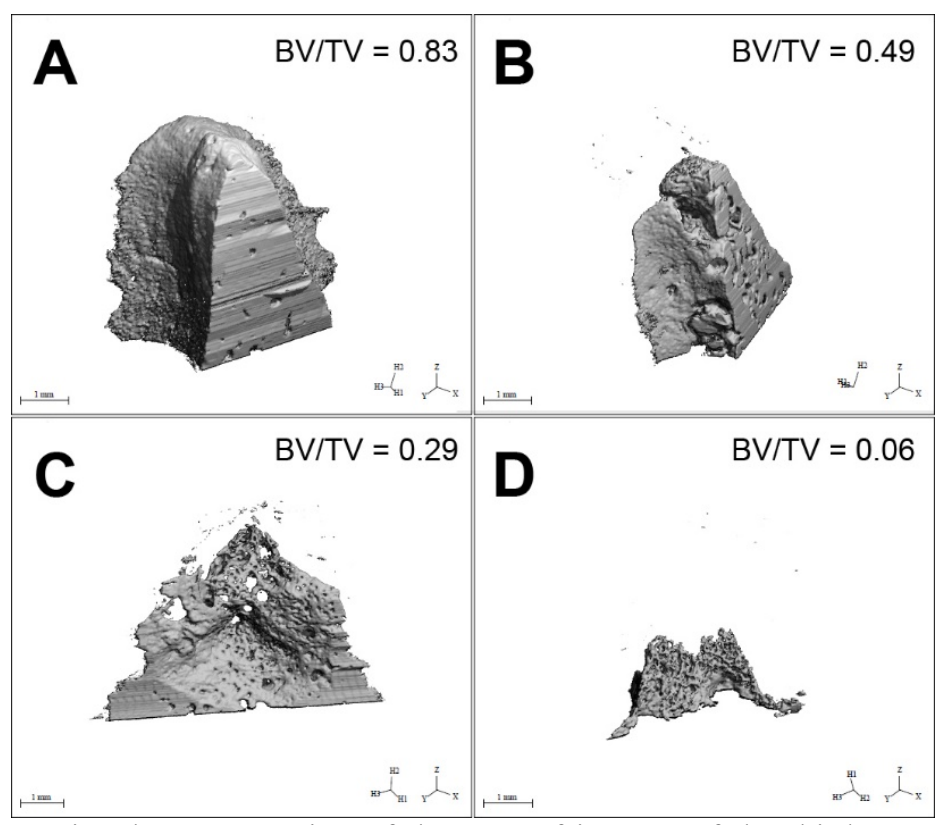

Figure 5. Three-dimensional reconstruction of the area of interest of the third premolar with a healthy alveolar bone (intact sample) (A), the sample with the highest BV/TV, belonging to the control group (B), a sample showing an intermediate value, also the control group $(\mathrm{C})$, and the sample with the lowest value for BV/TV, belonging to the treated group (D). These samples should not be taken as representative for the whole group, but show the difference in filling in the area of interest in the intact sample, especially in the coronal and vestibular portions of the defect.

The longitudinal analysis of histological sections allowed the visualization of the entire defect area, which was completely filled by well organized connective tissue. The same result was observed by Christgau et al.(2007), in a study of four different membranes, which demonstrated the presence of organized tissue two weeks after the application of guided tissue regeneration technique, which at four weeks, extensive bone formation can be observed, unlike results seen in this study. The formation of new trabecular bone was found to be restricted to the apical edge of the defect, in which active osteoblasts and bone extracellular matrix could be observed being deposited from the temporary matrix (Fig. 6A), similar to Reis et al. (2013).

There was no periodontal ligament formation in both the groups. This result differs from that found by Reis et al. (2011), in which the membrane used was composed of ceramic and polymer, and it was possible to visualize the formation of bone trabeculae in the furcation region and periodontal ligament along the dental root part.
In some samples, a layer of matrix was observed following the root of the tooth near the region where there was cementum, which was scraped off on the periodontal disease induction process, or even overlapping at points where it was still present (Fig.6B). These observations were similar in all groups. According to Cirelli et al. (1997), the conventional treatment of periodontal disease, the formation of cementum, periodontal ligament and alveolar bone does not occur or is minimal, limited to a small range on the basis of the defect. Although the histological staining used does not allow the differentiation between bone and cement, Sharpey's fibers were observed inserted in this tissue. The cross-sections showed that the proliferation of both connective tissue as epithelial was more exuberant in the control group samples. According to the definition of the guided tissue regeneration, the membrane acts as a barrier preventing gingival tissue and connective tissue to grow over the defect, facilitating the migration of cells from the periodontal tissue into the defect (Bosshardt and Sculean. 2009). However, the presence of juxtaposed epithelium to connective tissue within the furcation in the treated group showed that the 
membrane was not able to prevent invasion of epithelial tissue, but possibly has limited expansion of the two tissues. In addition, epithelial proliferation in the control group could be associated with the response of the flap itself, while in the group that received the membrane it was a second epithelial layer.

Both groups showed diffuse inflammatory infiltration of the connective tissue that filled the defect, however, this infiltration was more pronounced in areas near the proliferative epithelial tissue, and so it was more evident in the samples from the control group (Fig. 7C and D). This result is consistent with that found by Deliberador et al. (2006), in which the control treatment group made with calcium sulfate membranes showed high diffuse inflammatory infiltration. Lekovic et al. (1998), in a study of four membranes, one of polycaprolactone, results showed a good formation of cementum and alveolar bone, however, the membrane comprising polycaprolactone showed high inflammatory response, as seen in the present study.

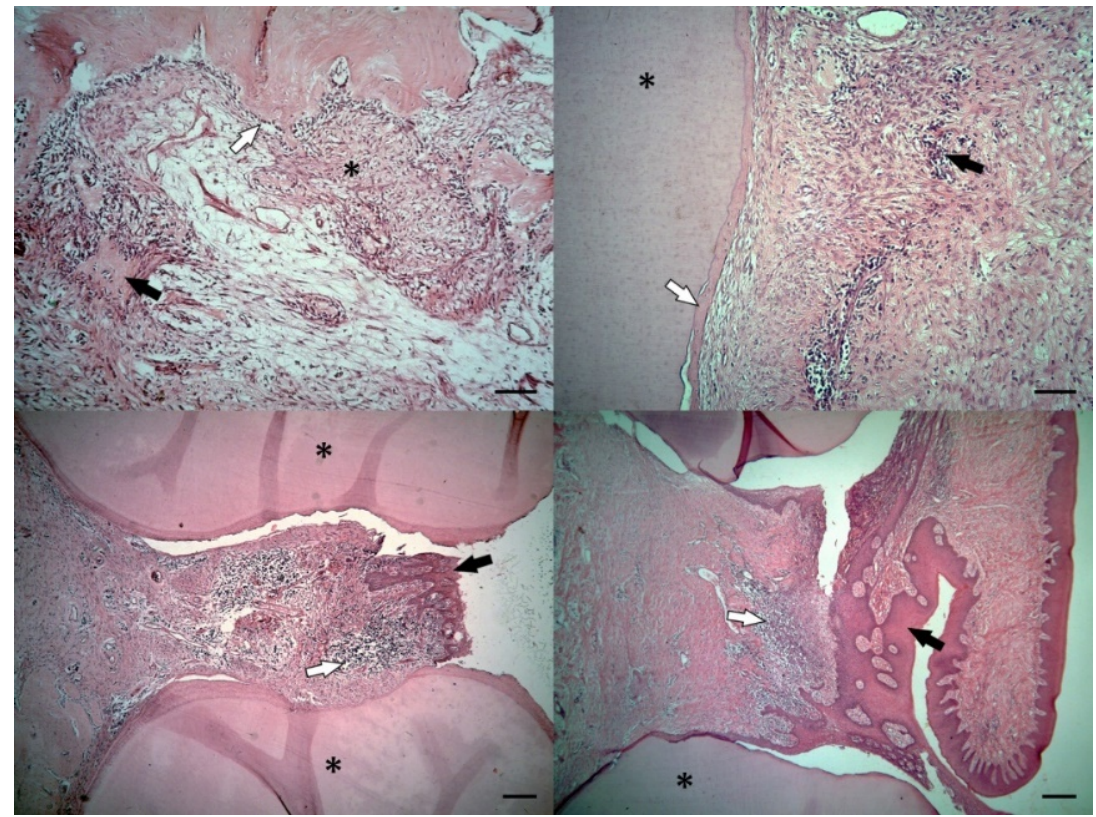

Figure 6. Photomicrograph of defect area in an animal from the treated group (A, B, and C) and control group (D), 60 days after treatment initiation. A: Defect base region; presence of active osteoblasts (black arrows), not organized extracellular matrix (asterisk) and formation of osteoid (white arrow). B: Edge of tooth root; matrix layer similar to bone (white arrows) covering the dentin (asterisk); the inflammatory infiltrate in the midst of connective tissue is also evident (black arrows). These observations were common to the control group. C and D: Furcation region of the third premolar in a treated animal and an animal control, respectively. Note the difference in the proliferation of epithelial tissue (black arrows) and connective tissue between the roots (asterisks). The white arrows point to the inflammatory infiltrate. Bar $=100$ microns.

\section{CONCLUSION}

Both study groups had connective tissue invasion into the bone defect, however, the use of membrane limited the amount of penetration greater gingival connective tissue in the treated group. However, it does not allow new bone forming cells to settle in the bone defect area. Besides the membrane having the ability to maintain the space of the defect by histological analysis it was shown biocompatible, but little osteoconductive characteristic also demonstrated by micro tomography. Despite the absence of clinical signs of inflammation, inflammatory reaction could be observed in the histological analysis in both groups. 


\section{ACKNOWLEDGMENT}

The authors would like to thank CNPq, CAPES, FAPEMIG, and JHS Laboratory Ltda. for financial support and Prof. J.E. Davies of the University of Toronto for micro tomography analysis.

\section{REFERENCES}

BORGES, A.P.B.; REZENDE, C.M.F.; RIBEIRO, M.F.B. et al. Hidroxiapatita sintética como substituto ósseo em defeito experimental provocado no terço proximal da tíbia em cão: aspectos à microscopia eletrônica de transmissão. Arq. Bras. Med. Vet. Zootec., v.52, p.616-620, 2000.

BOSSHARDT, D.D.; SCULEAN, A. Does periodontal tissue regeneration really work? Periodontolology 2000, v.51, p.206-219, 2009.

CHRISTGAU, M.; CAFFESSE, R.G.; SCHMALZ, G.; D'SOUZA, R.N. Extracellular matriz expression and periodontal wound-healing dynamics following guided tissue regeneration therapy in canine furcation defects. J. Clin. Periodontol. v.34, p.691-708, 2007.

CIRELLI, J.A.; MARCANTONIO JR, E.; ADRIANA, R. et al. Evaluation of anionic collagen membranes in the treatment of class II furcation lesions: an histometric analysis in dogs. Biomaterials, v.18, p.1227-1234, 1997.

DELIBERADOR, T.M; NAGATA, M.J.H; FURLANETO, F.A.C. et al. Autogenous bone graft with or without a calcium sulfate barrier in the treatment of class II furcation defects: a histologic and histometric study in dogs. J. Periodontol., v.77, p.780789, 2006.

ELZEIN, T.; NASSER-EDDINE, M.; DELAITE, C. et al. FTIR study of polycaprolactone chain organization at interfaces. J. Colloid Interface Sci., v.273, p.381-387, 2004.

FÍGUN, M.E.; GARINO, R.R. Sistema dental: anatomia odontológica funcional e aplicada. 3.ed. Rio de Janeiro: Panamericana, 1994. 451p.

FUJIHARA, K.; KOTAKI, M.; RAMAKRISHNA, S. Guided bone regeneration membrane made of polycaprolactone/calcium carbonate composite nanofibers. Biomaterials, v.26, p.4139-4147, 2004.
IWATA, T.; YAMATO, M.; TSUCHIOKA, H. et al. Periodontal regeneration with multi-layered periodontal ligament-derived cell sheets in a canine model. Biomaterials, v.30, p.2716-2723, 2009.

KINOSHITA, Y.; MATSUO, M.; TODOKI, K. et al. Alveolar bone regeneration using absorbable poly $(\mathrm{L}-$ lactide-co-epsilon-caprolactone)/beta-tricalcium phosphate membrane and gelatin sponge incorporating basic fibroblast growth factor. Int. J. Oral Maxillofac. Surg., v.37, p.275-281, 2008.

LEGENDRE, L. Intraoral acrylic splints for maxillofacial fracture repair. J. Vet. Dent., v.20, p.7078, 2003.

LEKOVIC, V.; KLOKKEVOLD, P.R.; KENNEY, E.B. et al. Histologic evaluation of guided tissue regeneration using 4 barrier membranes: a comparative furcation study in dogs. J. Periodontol., v.69, p.54-61, 1998.

MACEDO, T.C.N.; CRUZ, S.S.; SOLEDADE, K.R. et al. Comparação de critérios que determinam o diagnóstico clínico da doença periodontal. Rev. Odonto Ciênc., v.21, p.77-81, 2006.

PIHLSTROM, B.; MICHALOWICZ, B.; JOHNSON, N. Periodontal diseases. Lancet, v.366, p.1809-1820, 2005.

REIS, E.C.C.; BORGES, A.P.B; ARAUJO, M.V.F. et al. Periodontal regeneration using a bilayered PLGA/calcium phosphate construct. Biomaterials, v.32, p.9244-9253, 2011.

REIS, E.C.C.; BORGES, A.P.B; CARLO, R.J. et al. Guided tissue regeneration using rigid absorbable membranes in the dog model of chronic furcation defect. Acta. Odontol. Scand., v.71, p.372-380, 2013.

REZWAN, K.; CHEN, Q.Z.; BLAKER, J.J.; BOCCACCINI, A.R. Biodegradable and bioactive porous polymer/inorganic composite scaffolds for bone tissue engineering. Biomaterials, v.27, p.34133431, 2006.

SELVIG, K.A. Discussion: animal models in reconstructive therapy. J. Periodontol., v.65, p.11691172, 1994.

SEPÚLVEDA, R.V.; REIS, E.C.C.; VALENTE, F.L. et al. Evaluation of a model for induction of periodontal disease in dogs. Pesqui. Vet. Bras., v.34, p.562-568, 2014. 